\title{
IMPLEMENTASI TRANSAKSI NON TUNAI PADA TAMAN REKREASI SELECTA KOTA BATU JAWA TIMUR
}

\author{
Muhammad Ramadhan \\ mr.adhan02@gmail.com \\ Nihayatu Aslamatis Solekah \\ UIN Maulana Malik Ibrahim Malang
}

\begin{abstract}
Non-cash transactions are a form of payment system transformation that has touched various aspects of life, one of which is a tourist vehicle. Batu City is famous as Batu Tourism City because it has many tourist attractions, both natural and artificial tourism. One such vehicle is Selecta Recreational Park which is a business unit of PT.Selecta. Selecta Recreational Park is the only tourist attraction in Batu City which has implemented non-cash transactions in its operational activities. This study aims to examine the implementation of non-cash transactions in Selecta Recreational Park, Batu City, East Java. This study uses a qualitative descriptive approach using primary data through interview, observation, documentation and audiovisual techniques. To test the validity of the data in this study, researchers used triangulation techniques followed by data analysis with data reduction methods, data displays, conclusions and verification. The results of the study obtained information on the process of occurrence and the mechanism for implementing non-cash transactions in Selecta Recreational Park, so that it could produce a cooperative scheme and a non-cash transaction scheme in Selecta Recreational Park.
\end{abstract}

Key words: implementation; non-cash transactions; wahana wisata; selecta recreational park; batu city.

\begin{abstract}
ABSTRAK
Transaksi non tunai adalah bentuk transformasi sistem pembayaran yang telah menyentuh berbagai aspek kehidupan, salah satunya adalah wahana wisata. Kota Batu yang terkenal sebagai Kota Wisata Batu karena memiliki banyak wahana wisata, baik wisata alam maupun buatan. Salah satu wahana tersebut ialah Taman Rekreasi Selecta yang merupakan unit bisnis dari PT.Selecta. Taman Rekreasi Selecta menjadi satu - satunya wahana wisata di Kota Batu yang telah menerapkan transaksi non tunai pada kegiatan operasionalnya. Studi ini bertujuan untuk mengkaji implementasi transaksi non tunai pada Taman Rekreasi Selecta, Kota Batu, Jawa Timur. Studi ini menggunakan pendekatan kualitatif deskriptif dengan menggunakan data primer melalui teknik wawancara, observasi, dokumentasi dan audiovisual. Untuk menguji keabsahan data pada penelitian ini, peneliti menggunakan teknik triangulasi yang dilanjutkan analisis data dengan metode reduksi data, display data, conclusion dan verification. Hasil studi memperoleh informasi proses terjadinya dan mekanisme penerapan transaksi non tunai pada Taman Rekreasi Selecta, sehingga dapat menghasilkan skema kerjasama dan skema transaksi non tunai pada Taman Rekreasi Selecta.
\end{abstract}

Kata kunci: implementasi; transaksi non tunai; wahana wisata; taman rekreasi selecta; kota batu.

\section{PENDAHULUAN}

Perkembangan teknologi yang semakin maju telah menyentuh berbagai aspek dalam kehidupan termasuk aspek ekonomi. Perkembangan teknologi yang telah menyentuh aspek ekonomi dapat dilihat dari munculnya mesin Automatic Teller Machine (ATM) yang mempermudah nasabah dalam pengambilan uang dan melakukan transfer tanpa harus mendatangi bank, bisnis berbasis online, hingga proses transaksi yang menggunakan chip based dan server based atau lebih dikenal dengan transaksi non tunai. Adiyanti dalam 
Abidin (2015) menyebutkan perkembangan teknologi telah membawa suatu perubahan kebutuhan masyarakat atas suatu alat pembayaran yang dapat memenuhi kecepatan, ketepatan, dan keamanan dalam setiap transaksi elektronik. Dalam perkembangannya, sistem pembayaran secara elektronik atau biasa disebut non tunai sangat dipengaruhi oleh kemajuan perkembangan teknologi dan perubahan pola hidup masyarakat. Kartika dan Nugroho (2015) menyatakan dalam hasil penelitiannya jika PDB, pasokan uang dan perputaran uang meningkat, maka uang eletronik juga akan meningkat.

Meskipun "cashless society" memiliki beberapa keunggulan aktivis lingkungan dan social menyatakan keprihatinannya dikarenakan hal tersebut meningkatkan konsumsi secara keseluruhan, meningkatkan hutang pribadi, mengurangi tabungan, serta meningkatnya konsumsi yang berlebihan bisa memiliki dampak yang buruk terhadap masyarakat dan lingkungan (Libow, 1955; Zavestoski, 2002; dan McDonald et al., 2006). Selain itu beberapa penelitian sebelumnya menyarankan bahwa konsumen akan me- ngalami masalah dengan psykologinya ketika berpisah dengan uang tunai dengan alasan bahwa fisik uang tunai menciptakan kesadaran bahwa sesuatu yang bernilai sedang ditransfer (Prelec dan Loewenstein, 1998; Raghubir dan Srivastava, 2008; Soman, 2003; Thomas et al., 2011). Soman (2001, 2003) menemukan bahwa penggunaan kartu prabayar meningkatkan jumlah pengeluaran untuk transaksi. Namun karena uang tersebut ditransfer sehingga dapat digunakan untuk tujuan tertentu mungkin ada kesadaran bahwa uang itu dihabiskan. Thaler (1985; 1999) dan Gourville dan Soman (1998) menjelaskan fenomena ini sebagai efek biaya pseudo-sunk.

Transaksi non tunai yang dijadikan sebagai salah satu sistem bertransaksi memunculkan suatu alat pembayaran non tunai yang disebut alat pembayaran menggunakan kartu (APMK). Adapun produk dari APMK yang digunakan masyarakat saat ini ialah kartu debet atau ATM, kartu kredit dan uang elektronik. Berikut disajikan Tabel 1 perkembangan instrumen non tunai di Indonesia, sebagai berikut:

Tabel 1

Perkembangan Instrumen Non Tunai di Indonesia

\begin{tabular}{ccccccc}
\hline Non Tunai & \multicolumn{2}{c}{ Kartu Kredit } & \multicolumn{2}{c}{ Kartu Debet } & \multicolumn{2}{c}{ Uang Elektronik } \\
\hline Tahun & $\begin{array}{c}\text { Volume } \\
\text { (Juta Trns) }\end{array}$ & $(\%)$ & $\begin{array}{c}\text { Volume } \\
\text { (Juta Trns) }\end{array}$ & $(\%)$ & $\begin{array}{c}\text { Volume } \\
\text { (Juta Trns) }\end{array}$ & $(\%)$ \\
\hline 2009 & 17.508 .233 & - & 148.986 .974 & - & 2.037 .268 & - \\
2010 & 18.488 .839 & 5,60 & 170.673 .810 & 14,55 & 2.898 .167 & 42,25 \\
2011 & 18.717 .892 & 1,23 & 219.095 .179 & 28,37 & 4.669 .233 & 61,10 \\
2012 & 20.067 .650 & 7,21 & 269.571 .843 & 23,03 & 10.260 .989 & 197,57 \\
2013 & 21.806 .463 & 8,66 & 324.053 .412 & 20,21 & 12.442 .672 & 21,26 \\
2014 & 24.464 .977 & 12,19 & 382.222 .638 & 17,95 & 26.154 .071 & 101,96 \\
2015 & 26.805 .021 & 9,56 & 426.658 .783 & 11,62 & 41.606 .578 & 59,08 \\
2016 & 28.349 .527 & 5,76 & 475.610 .928 & 11,47 & 79.228 .422 & 90,42 \\
\hline
\end{tabular}

Sumber: Bank Indonesia (diolah peneliti, 2018)

Berdasarkan Tabel 1 diatas dapat dilihat bahwa dalam setiap tahunnya terjadi kenaikan jumlah transaksi dari berbagai produk, baik itu kartu debet atau ATM, kartu kredit maupun uang elektronik, hal ini mengindikasikan bahwa masyarakat semakin sering menggunakan transaksi non tunai dalam aktivitas ekonominya. Ariyani (2016) menyatakan bahwa faktor manfaat, kepercayaan, kemudahan dan gaya hidup 
merupakan faktor-faktor yang mempengaruhi konsumen dalam menggunakan non tunai. Selanjutnya Dehghan dan Haghighi (2015) juga menyatakan bahwa $e$ money adalah sistem pembayaran yang efisien dan mudah digunakan baik di dunia nyata maupun dunia maya. Helmi dan Mubarak (2014) menyatakan bahwa faktor kemudahan dan keamanan menyebabkan pengguna memanfaatkan sistem pembayaran non tunai.

Dalam perkembangan sistem pembayaran non tunai, bidang pariwisata tidak ketinggalan dalam berinovasi dimana pariwisata merupakan salah satu destinasi yang mempunyai peranan yang sangat strategis dalam menunjang perekonomian. Sektor ini dicanangkan selain sebagai salah satu sumber penghasil devisa yang cukup handal, juga merupakan sektor yang mampu menyerap tenaga kerja dan mendorong perkembangan investasi (Yuningsih, 2005: 23). Perkembangan kepariwisataan memegang peranan penting sebagai pusat pengembangan dan pertumbuhan ekonomi di dalam menciptakan iklim yang sehat dan dinamis melalui pengelolaan kegiatan usaha dan kepariwisataan di daerah. Dengan adanya kegiatan pariwisata dapat menjadi sarana untuk menjaga dan memperbaiki lingkungan dan mendorong pembangunan ekonomi regional. Dengan demikian pari wisata dipandang dapat mengurangi jumlah pengangguran yang bertujuan sebagai penopang perekonomian masyarakat (Pramudita et al., 2013).

Kota Batu yang dikenal sebagai Kota Wisata Batu memiliki banyak wahana wisata, mulai dari wisata alam hingga wisata buatan. Taman Rekreasi Selecta merupakan salah satu wahana wisata yang ada di Kota Batu. Berdasarkan informasi yang diberikan oleh Putri Sohfia selaku asisten manajer pengawasan sistem pembayaran Kantor Perwakilan Bank Indonesia Malang bahwa Taman Rekreasi Selecta merupakan satusatunya wahana wisata yang telah menerapkan transaksi non tunai pada kegiatan operasionalnya. Penerapan tersebut dilakukan untuk memberikan kemudahan bagi pengunjung untuk menikmati destinasi wisatanya tanpa menggunakan uang tunai sehingga dapat menekan biaya transaksi.

Berdasarkan pada fenomena yang telah diamati dan hasil-hasil dari studi terdahulu sebagimana yang telah diuraikan diatas, maka yang menjadi fokus masalah pada studi ini adalah implementasi transaksi non tunai pada Taman Rekreasi Selecta, Kota Batu, Jawa Timur. Selain itu, studi ini juga mengkaji keterkaitan Kantor Perwakilan Bank Indonesia Malang selaku regulator kebijakan dengan PT. Selecta selaku pelaksanaan kebijakan yang bersedia menerapkan transaksi non tunai pada unit bisnisya, yaitu Taman Rekreasi Selecta. Sehingga dapat mengetahui prosedur dalam penerapan transaksi non tunai dan bagaimana implementasi yang terjadi di lapangan.

Adapun tujuan studi ini adalah untuk mengetahui proses untuk menerapkan transaksi non tunai dan implementasi transaksi non tunai pada Taman Rekreasi Selecta, Kota Batu, Jawa Timur yang merupakan satu satunya wahana wisata di Kota Batu yang menerapkan transaksi non tunai pada kegiatan operasionalnya, sehingga menghasilkan skema berupa proses terjadinya transaksi non tunai dan skema implementasi transaksi non tunai tersebut pada Taman Rekreasi Selecta. Dengan begitu diharapkan studi ini dapat dijadikan sebagai rujukan bagi stakeholders wahana wisata lainnya untuk menerapkan transaksi non tunai pada wahana wisata yang dikelolanya.

\section{TINJAUAN TEORITIS \\ Penelitian Terdahulu}

Dari hasil penelitian-penelitian terdahulu terdapat hasil-hasil yang bersifat positif terhadap transaksi non tunai dan ada juga yang bersifat negatif sesuai dengan penemuan dilapangan. Studi menunjukkan bahwa jumlah yang dihabiskan untuk penggunaan e money seperti kartu kredit dibandingkan dengan uang tunai mengalami peningkatan (Hirschman, 1979; Feinberg, 1986; McCall dan Belmont, 1996; Prelec dan Loewenstein, 1998; Prelec dan Simester, 2001; Soman, 2001; 2003; McCall et 
al., 2004; Raghubir dan Srivastava, 2008). Ada bukti bahwa jenis karakteristik pembelian mempengaruhi mode pembayaran serta berkorelasi tinggi dengan penggunaan kartu debit (maupun kredit) (Bounie dan Francois, 2009; Singh, 2004).

Helmi dan Mubarak (2014) menjelaskan bahwa motivasi dalam menggunakan transaksi non tunai dikarenakan kemudahan, tidak perlu repot membawa uang tunai (praktis), dan juga transaksi bersifat aman. Dehghan dan Haghighi (2015) menyatakan bahwa uang elektronik adalah sistem pembayaran yang efisien dan mudah digunakan, karena bersifat umum dan dapat digunakan di dunia nyata maupun dunia maya. Selanjutnya Ariyani (2016) juga memaparkan bahwa faktor-faktor yang mempengaruhi minat konsumen dalam menggunakan transaksi non tunai adalah faktor manfaat, kepercayaan, kemudahan dan gaya hidup sehingga konsumen menggunakan transaksi non tunai pada kegiatan bertransaksinya. Ozturk (2016) juga menunjukkan dalam hasil studinya bahwa faktor kondisi mempengaruhi persepsi seseorang dalam menggunakan transaksi non tunai. Selain itu, secara makro Kumari dan Khanna (2017) memaparkan bahwa penerapan kebijakan transaksi non tunai pada kegiatan perekonomian dapat meningkatkan pertumbuhan stabilitas keuangan negara, karena pengembangan ekonomi yang dilakukan secara non tunai sangat bermanfaat dalam pengembangan ekonomi tersebut, seperti memerangi korupsi dan pencucian uang.

Wulandari et al. (2016) mengungkapkan bahwa hanya $17,07 \%$ responden (mahasiswa Fakultas Ekonomi Universitas Negeri Malang) yang menggunakan transaksi non tunai dalam hal ini adalah Brizzi, sedangkan $82,93 \%$ nya lagi tidak menggunakan transaksi non tunai dikarenakan persepsi yang menganggap bahwa penggunaan non tunai akan mendorong konsumtivitas dan penggunaan non tunai tidak menjaga keamanan dan kerahasiaan data customer. Selain itu, mahasiswa lebih suka menggunakan transaksi yang bersifat tunai dikarenakan nominal yang mereka gunakan dalam jumlah yang sedikit dan jika menggunakan non tunai akan menambah beban biaya.

Kumari dan Khanna (2017) dalam penelitiannya yang dilakukan di India mengungkapkan bahwa menetapkan sebuah kebijakan yang dapat meningkatkan penggunaan non tunai itu sangatlah penting. Dalam temuannya kebijakan non tunai dapat meningkatkan stabilitas keuangan, hal ini disebabkan oleh kebijakan Negara yang mendorong masyarakat untuk menggunakan transaksi non tunai. Selain itu, kebijakan penggunaan non tunai juga memberikan banyak manfaat diantaranya membantu untuk memberantas korupsi, pencucian uang, perampokan, dan akan memecahkan permasalahan sektor keuangan karena peredaran uang di masyarakat.

Disisi lain, hasil temuan Helmi dan Mubarak (2014) juga menyatakan bahwa masyarakat yang paling banyak dalam menggunakan non tunai ialah masyarakat yang berpenghasilan tinggi daripada yang berpenghasilan rendah. Ariyani (2016) juga menemukan bahwa faktor risiko membuat konsumen takut dalam menggunakan transaksi non tunai. Dan juga yang ditemukan oleh Wulandari et al. (2016) bahwa masyarakat masih sangat loyal dalam menggunakan uang tunai dan rendahnya pengetahuan terhadap penggunaan transaksi non tunai.

Ada 4 (empat) faktor yang akan menjadi sumber masalah sekaligus sebagai prakondisi menuju keberhasilan proses implementasi, yaitu komunikasi, sumber daya, sikap birokrasi atau pelaksana, dan struktur organisasi termasuk tata aliran kerja birokrasi (Akib, 2010). Tiga faktor yang dapat mengukur keberhasilan komunikasi, yaitu transmisi, kejelasan dan kosistensi (Abdussakur, 2012): Dengan berdasarkan temuan-temuan diatas dapat diamati sisi positif dan negatif terhadap transaksi non tunai sehingga perlunya dikaji implementasi transaski non tunai tersebut berdasarkan perspektif yang berbeda dengan temuantemuan pada studi terdahulu. 


\section{Sistem Pembayaran}

Sistem pembayaran adalah suatu sistem yang mencakup pengaturan, kontrak atau perjanjian, fasilitas operasional, dan mekanisme teknis yang digunakan untuk penyampaian, pengesahan dan penerimaan instruksi pembayaran, serta pemenuhan kewajiban, pembayaran melalui pertukaran nilai antarperorangan, bank dan lembaga lainnya baik domestik maupun cross border antar negara. Ada 4 (empat) komponen yang menjadi pembentuk sistem pembayaran, yaitu (Subari dan Ascarya, 2003:2-4):

a. Lembaga yang menyediakan jasa pembayaran.

b. Instrumen yang digunakan dalam sistem pembayaran yang mengatur hak dan kewajiban keuangan peserta pembayaran.

c. Kerangka hukum yang mengatur ruang lingkup hukum dan instrumen sistem pembayaran, hak dan kewajiban peserta, sanksi, dan aturan lainnya untuk menjamin terlaksananya sistem pembayaran secara hukum.

d. Kerangka kebijakan sistem pembayaran yang jelas, baik kebijakan umum maupun operasional, yang mendasari pengembangan sistem pembayaran.

Dengan terpenuhinya komponen-komponen tersebut merupakan suatu keharusan agar dapat terlaksananya sistem pembayaran dengan baik, hal ini dikarenakan sistem pembayaran merupakan suatu bagian yang tidak dapat dipisahkan dari kehidupan masyarakat. Sadar atau tidak, dalam kegiatan kesehariannya para pelaku ekonomi melakukan transaksi yang merupakan suatu kegiatan ekonomi yang berkaitan erat dengan sistem pembayaran. Bagi suatu Negara, sistem pembayaran merupakan suatu yang penting, hal ini dikarenakan sistem pembayaran dijadikan sebagai tolak ukur terhadap maju atau mundurnya ekonomi suatu Negara. Efektivitas dan kelancaran perekonomian suatu Negara sangat bergantung pada mekanisme dan sistem pembayaran yang dimiliki. Selain itu, Sheppard juga menyampaikan pentingnya sistem pembayaran bagi perekonomian, yaitu (Bank Indonesia, 2006:9-10):

a. Elemen penting untuk menciptakan stabilitas sistem keuangan.

b. Untuk mendukung kebijakan moneter yang lebih efektif dan efisien.

c. Untuk mendorong efisiensi perekonomian nasional.

Untuk merealisisasikan peran tersebut, sistem pembayaran memiliki 4 (empat) prinsip dasar yang harus terpenuhi agar dapat menyelenggarakan, mengembangkan dan mengawasi sistem pembayaran agar berjalan secara baik. Adapun prinsip-prinsip tersebut ialah pengendalian risiko, efisiensi, kesetaraan akses dan perlindungan konsumen (Bank Indonesia, 2012:8-11):

a. Prinsip pengendalian risiko muncul dikarenakan adanya aktifitas pemindahan dana dari satu pihak ke pihak lain yang berpotensi mengandung berbagai risiko.

b. Prinsip efisiensi muncul dikarenakan adanya upaya untuk mengembangkan sistem pembayaran melalui penyempurnaan mekanisme operasional dalam rangka menekan biaya, baik biaya waktu maupun proses settlement. Secara ekonomi prinsip efisiensi ditekankan pada aspek economics scope and scale.

c. Prinsip kesetaraan akses muncul untuk memberikan keseimbangan hak dan kewajiban kepada seluruh pelaku sistem pembayaran baik penyedia jasa maupun pengguna jasa pembayaran, termasuk memperoleh pelayanan yang sama diberbagai wilayah.

d. Prinsip perlindungan konsumen adalah prinsip yang muncul agar penyelenggara wajib menerapkan akses perlindungan konsumen kepada setiap penggunanya secara wajar dalam kegiatan operasionalnya, sehingga terjadinya keseimbangan hak dan kewajiban antara penyedia dan penyelenggara dengan pengguna layanan jasa pembayaran.

\section{Transaksi Non Tunai}

Bank Indonesia selaku otoritas moneter dan regulator atas sistem pembayaran membuat suatu strategi untuk menanggulangi 
permasalahan tersebut, yakni dengan Gerakan Nasional Non Tunai (GNNT). Pada tanggal 14 Agustus 2014 GNNT diresmikan oleh Gubernur Bank Indonesia Agus D.W Martowardojo. Pencanangan strategi ini ditandai dengan penandatanganan Nota Kesepahaman antara Bank Indonesia dengan Kementerian Koordinator Bidang Perekonomian, Kementerian Keuangan, Pemerintah Daerah serta Asosiasi Pemerintah Provinsi Seluruh Indonesia sebagai bentuk komitmen dalam mendukung GNNT. Agus D.W Martowardojo menuturkan bahwa GNNT ditujukan untuk meningkatkan kesadaran masyarakat agar menggunakan instrumen non tunai, sehingga secara berangsur-angsur dapat terbentuk masyakarat non tunai (less cash society) yang lebih banyak melakukan transaksi non tunai khususnya atas kegiatan ekonomi (Segara, 2014). Peresmian tersebut didasari mulai tidak efisiennya pembayaran secara tunai. Ketidak efisienan tersebut disebabkan oleh beberapa faktor, diantaranya (http://www.nontunai.com/):

a) Biaya yang besar dalam pengelolaan uang rupiah meliputi perencanaan, pencetakan, pengeluaran, pengedaran, pencabutan dan penarikan serta pemusnahan yang dilakukan oleh Bank Indonesia.

b) Kerepotan bertransaksi dimana adanya kesulitan dalam penyediaan uang kembalian dan juga antrian yang panjang dikarenakan waktu yang dibutuhkan dalam bertransaksi dengan pelayanan yang relatif lambat.

c) Tidak tercatatnya transaksi (kurang transparan) yang akhirnya memberian peluang tindak kejahatan.

d) Sulit melakukan transaksi dalam jumlah besar yang harus menyediakan dan membawa uang dalam jumlah besar pula sehingga tidak praktis dan memakan ruang serta juga ada kekhawatiran terhadap keamanan dalam membawa sejumlah uang oleh pengguna pembayaran tunai.

Sejalan dengan perkembangan teknologi yang pesat, pola dan sistem pembayaran dalam transaksi ekonomi terus mengalami perubahan. Kemajuan teknologi dalam sistem pembayaran menggeser peranan uang tunai sebagai alat pembayaran dalam bentuk pembayaran non tunai yang lebih efisien dan ekonomis. Dalam perkembangannya, lembaga penyedia jasa pembayaran semakin inovatif dalam menyediakan berbagai alternatif jasa pembayaran non tunai berupa sistem transfer dan alat pembayaran menggunakan kartu elektronik yang aman, cepat dan efisien serta bersifat global (Pramono et al., 2006:1).

Kartu debit dan kredit memiliki karakteristik yang sama dalam hal akses uang "virtual" dalam jumlah besar dengan tingkat keamanan yang tinggi (Mann, 2002).

\section{a. Kartu Kredit}

Penelitian penggunaan kartu kredit pertama kali dilakukan oleh Mathews dan Slocum (1969, 1970) dan Plummer (1971). Studi Plummer (1971) menunjukkan bahwa minat penggunaan kartu kredit meningkat baik diperkotaan maupun dipinggiran kota. Hasil penelitian tersebut juga selaras dengan Goldstrucker dan Hirschman (1977); Hirschman (1979); dan Martell dan Fitts (1981). Choe et al., (1991) melaporkan bahwa dalam konteks orang tua tunggal laki-laki lebih cenderung menggunakan kartu kredit, untuk wanita yang memiliki penghasilan lebih tinggi juga cenderung menggunakan kartu kredit. Namun tampaknya terdapat hasil penelitian yang konsisten bahwa pendapatan dan pendidikan memengaruhi kepemilikan dan penggunaan kartu kredit (Klee 2004; Lee dan Kwon 2002)

Kartu kredit merupakan kartu yang dikeluarkan oleh bank atau lembaga pembiayaan lainnya yang diberikan kepada nasabah untuk dapat dipergunakan sebagai alat pembayaran dan pengambilan uang tunai. Transaksi yang dilakukan dengan menggunakan kartu kredit melibatkan berbagai pihak yang saling berkepentingan, yang masing-masing terikat dalam suatu perjanjian. Dalam mekanisme penggunaan kartu kredit terdapat sedikitnya tiga pihak 
yang terlibat langsung untuk setiap transaksi penggunaan dan pembayaran kartu kredit. Pihak-pihak dimaksud adalah bank atau lembaga pembiayaan, merchant (pedagang), dan card holder (pemegang kartu) (Subari dan Ascarya, 2003: 41-42).

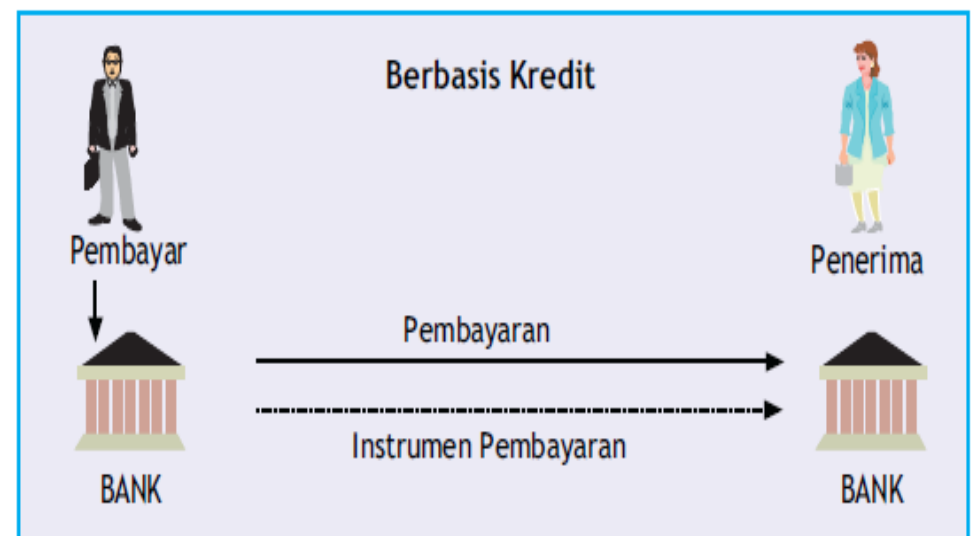

\section{Gambar 1 \\ Mekanisme Kredit \\ Sumber: Subari dan Ascarya, 2003:11}

\section{b. Kartu Debet}

Studi awal yang dilakukan Prendergast (1993) menemukan bahwa penggunaan kartu debit secara signifikan lebih banyak digunakan oleh kalangan muda di Selandia Baru. Borzekowski et al. (2006) menemukan bahwa beberapa penelitian di Amerika Serikat, yang menggunakan berbagai survei keuangan konsumen semuanya menunjukkan bahwa pengguna kartu debit adalah kalangan muda, berpendidikan tinggi dan lebih banyak digunakan oleh wanita. Hasil tersebut selaras dengan di negara Belgia dan Austria (Foscht et al., 2010)

Kartu debet merupakan instrumen pembayaran berbasis kartu yang pembayarannya dilakukan dengan pendebetan langsung ke rekening nasabah di bank penerbit kartu tersebut. Pada beberapa bank penerbit kartu debet terdapat kombinasi fungsi kartu debet dan kartu ATM dalam satu kartu sekaligus (kartu debet dan kartu ATM) (Subari dan Ascarya, 2003:43).

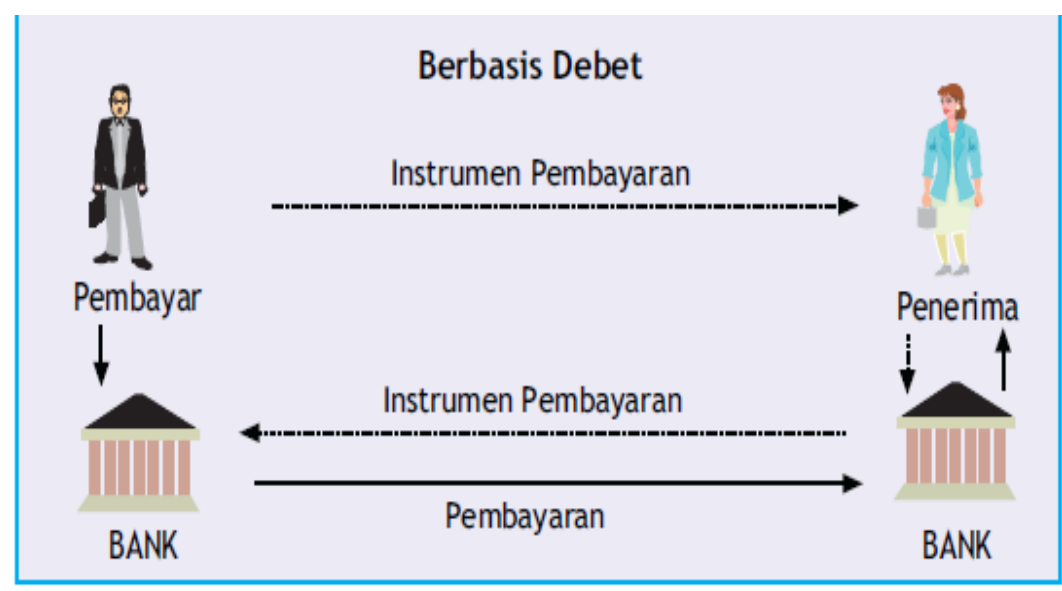

Gambar 2

Mekanisme Debet

Sumber: Subari dan Ascarya, 2003:11 
c. Kartu ATM

Kartu ATM merupakan penggunaan transaksi yang dilakukan melalui mesin ATM. Pelayanan yang diberikan ATM antara lain (Subari dan Ascarya, 2003:42 - 43):

1. Penarikan uang tunai yang dapat dilakukan nasabah di berbagai ATM yang memiliki hubungan dengan bank penerbit kartu ATM.

2. Untuk melihat, mengecek, meminta atau mencetak saldo rekening pemegang atau nasabah.

3. Pelayanan pembayaran lainnya, seperti pembayaran listrik, telpon, kartu kredit, transfer uang, dan lain-lain.

\section{d. Uang Elektronik}

Bank for International Settlement (BIS) pada bulan Oktober 1996 mendefinisikan uang elektronik merupakan produk yang memiliki nilai tersimpan (stored-value) atau prabayar (prepaid) dimana sejumlah uang disimpan dalam suatu media elektronis yang dimiliki seseorang. Uang elektronik (emoney) merupakan alat pembayaran yang dapat digunakan untuk berbagai macam jenis pembayaran (multi purposed) (Ramadani, 2016). Yang karakteristiknya sedikit berbeda dengan pembayaran elektronik yang telah disebutkan sebelumnya karena pembayaran dengan menggunakan e-money tidak selalu memerlukan proses otorisasi untuk pembebanan ke rekening nasabah yang menggunakannya. Hal ini dikarenakan pada e-money tersebut telah terekam sejumlah nilai uang (Bank Indonesia, 2006).

\section{Kepariwisataan}

Pariwisata merupakan fenomena yang sangat kompleks dan bersifat unik, karena pariwisata bersifat multidimensi baik secara fisik, sosial, ekonomi, politik dan budaya. Pariwisata juga menawarkan jenis produk dan wisata yang beragam, mulai dari wisata alam, wisata budaya, wisata sejarah, wisata buatan hingga beragam wisata minat khusus (Parikeit dan Trisnadi, 1997). Menurut Chafid Fandeli obyek wisata adalah perwujudan daripada ciptaan manusia, tata hidup, seni budaya serta sejarah bangsa dan tempat atau keadaan alam yang mempunyai daya tarik untuk dikunjungi wisatawan (Yuningsih, 2005:18).

Basis pengembangan pariwisata adalah potensi sumber daya keragaman budaya, seni, dan alam (pesona alam). Pengembangan sumber daya tersebut dikelola melalui pendekatan peningkatan nilai tambah sumber daya secara terpadu antara pengembangan produk pariwisata dan pengembangan pemasaran pariwisata melalui pendekatan pemberdayaan masyarakat lokal dalam rangka pengembangan pariwisata (Yuningsih, 2005: 19-20). Hadiwijoyo (2012:49) berpendapat bahwa objek dan daya tarik wisata adalah suatu bentukan dan fasilitas yang berhubungan, yang dapat menarik minat wisatawan atau pengunjung untuk datang ke suatu daerah atau tempat tertentu, dimana objek dan daya tarik wisata merupakan dasar bagi kepariwisataan. Menurut Sunaryo, 2000 (dalam Yuningsih, 2005:28) di lihat dari makna ekonomi, pembangunan kepariwisataan nasional diharapkan mampu menggalakkan kegiatan ekonomi. Selanjutnya di dalam UU No.10 tahun 2009 turut dijelaskan pada Bab 2 Pasal 4 Ayat 1-10 bahwa kepariwisataan bertujuan untuk:

a. Meningkatkan pertumbuhan ekonomi.

b. Meningkatkan kesejahteraan rakyat.

c. Menghapus kemiskinan.

d. Mengatasi pengangguran.

e. Melestarikan alam, lingkungan dan sumber daya.

f. Memajukan kebudayaan.

g. Mengangkat citra bangsa.

h. Memupuk rasa cinta tanah air.

i. Memperkukuh jati diri dan kesatuan bangsa.

j. Mempererat persahabatan antar bangsa.

\section{METODE PENELITIAN}

Penelitian ini menggunakan metode kualitatif deskriptif. Riset naratif sebagai tipe desain kualitatif yang spesifik yang narasinya dipahami sebagai teks yang dituturkan dan dituliskan dengan menceritakan tentang peristiwa atau aksi yang terhubung secara kronologis. Prosedur dalam penelitian ini 
memfokuskan pada pengkajian terhadap satu atau dua subyek, pengumpulan data melalui cerita mereka, pelaporan melalui hasil pengalaman, dan penyusunan laporan atas makna dari setiap pengalaman yang dipaparkan (Creswell, 2015:96). Peneliti mengkaji implementasi transaksi non tunai yang terjadi di Taman Rekreasi Selecta yang berada di Jalan Raya Selecta No.1, Bumiaji, Tulungrejo, Kota Batu.

Informan dalam penelitian ini terbagi menjadi dua, yaitu stakeholder Kantor Perwakilan Bank Indonesia Malang selaku regulator kebijakan (Putri Sohfia selaku asisten manajer pengawasan sistem pembayaran Kantor Perwakilan Bank Indonesia Malang selaku regulator kebijakan transaksi non tunai dan Tri Prasetyo Aribowo selaku pelaksana pengawasan sistem pembayaran Kantor Perwakilan Bank Indonesia Malang selaku regulator kebijakan transaksi non tunai) dan stakeholder PT.Selecta (Sujud selaku direktur PT. Selecta danTri Suhartin selaku accounting PT. Selecta). Jenis data dalam penelitian ini terbagi menjadi dua, yaitu primer dan sekunder. Data primer yang diperoleh secara langsung dengan cara observasi, wawancara, dokumentasi, serta audio dan visual terhadap subyek penelitian, sedangkan data sekunder diperoleh melalui media hasil publikasi berupa working paper, informasi dari website resmi Bank Indonesia (BI) yang berkaitan dengan transaksi non tunai, dan berita-berita media yang terkait dengan penerapan transaksi non tunai. Teknik pengumpulan data kualitatif yang paling independen terhadap semua metode pengumpulan data dan teknik analisis data adalah metode wawancara, observasi, bahan dokumenter, serta metode-metode baru seperti metode bahan visual dan metode penelusuran bahan internet (Bungin, 2015:110).

Untuk menguji keabsahan hasil penelitian menggunakan meode triangulasi sumber data, metode dan teori (Bungin, 2015:264). Analisis data dilakukan pada pra penelitian dan saat penelitian (Sugiyono, 2013:429-434). Analisis pra penelitian dilakukan terhadap data hasil studi pendahuluan, atau data sekunder yang digunakan untuk menentukan fokus penelitian. Analisis saat penelitian dilakukan dengan tiga tahap, yaitu reduksi data, display data, conclusion dan verification. Mereduksi data berarti merangkum, memilih hal-hal yang pokok, memfokuskan pada hal-hal yang penting, dicari tema dan polanya dan membuang yang tidak perlu. Miles dan Huberman (2007:59) menyatakan yang paling sering digunakan untuk menyajikan data dalam penelitian kualitatif adalah dengan teks yang bersifat naratif. Jika kesimpulan pada tahap awal kemudian di dukung oleh bukti-bukti yang valid dan konsisten pada saat peneliti di lapangan, maka kesimpulan yang dikemukakan merupakan kesimpulan yang kredibel.

\section{ANALISIS DAN PEMBAHASAN Produk Non Tunai}

Penerapan transaksi non tunai pada Taman Rekreasi Selecta yang diinisiasi oleh Kantor Perwakilan Bank Indonesia Malang telah berlangsung sejak akhir 2016. Pada awalnya Kantor Perwakilan Bank Indonesia Malang menawarkan 2 pilihan kepada PT.Selecta untuk menentukan produk non tunai yang akan digunakan sebagai media transaksi. Kedua tawaran tersebut, yaitu membuat alat non tunai sendiri berupa kartu atau koin khusus layaknya timezone atau menggunakan alat non tunai yang berskala nasional seperti kartu debet atau ATM, kartu kredit dan uang elektronik. Selanjutnya manajemen PT. Selecta memutuskan menggunakan alat non tunai berskala nasional sebagai alat transaksi non tunai yang diterapkan di Taman Rekreasi Selecta.

Manajemen PT. Selecta meyakini bahwa kedepannya transaksi non tunai akan berkembang dengan pesat dan menggunakan alat non tunai yang telah diakui secara nasional akan mempermudah proses transaksi yang berlangsung pada PT.Selecta, terutama pada Taman Rekreasi Selecta. Dengan keputusan tersebut, PT.Selecta kemudian menjalin kerjasama dengan pihak perbankan yang telah bersedia bekerjasama dengan Kantor Perwakilan Bank Indonesia 
Malang untuk menggencarkan Gerakan Nasional Non Tunai, yaitu Bank Mandiri, BRI, BCA, BNI dan Bank Mega.

Dalam perjalanannya transaksi non tunai pada Taman Rekreasi Selecta per Maret
2018 telah mencapai total pendapatan sebesar Rp 3.142.166.374. Adapun grafik pendapatan transaksi non tunai PT.Selecta, sebagai berikut ini:

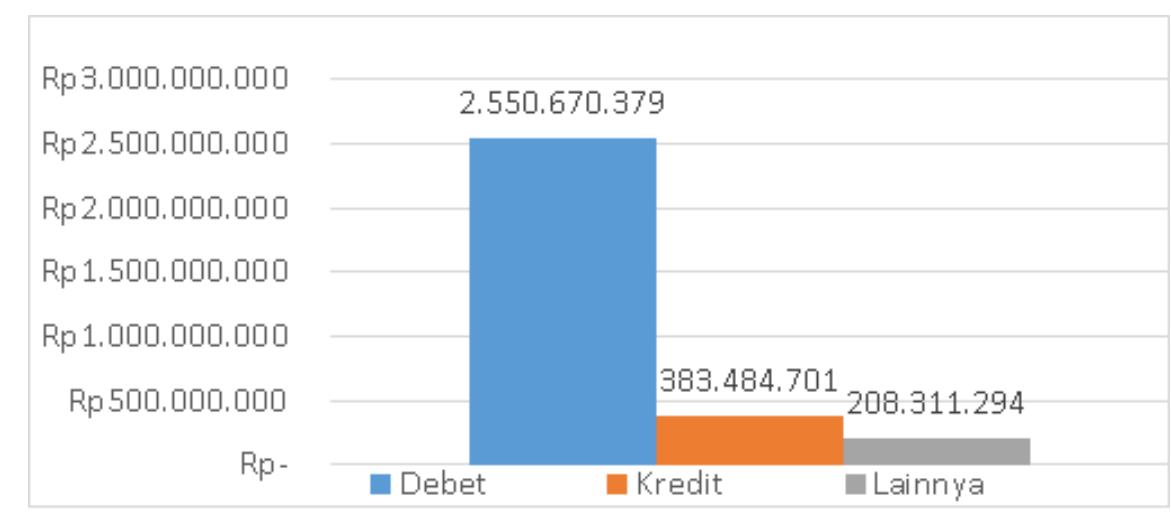

Gambar 3

\section{Grafik Pendapatan Transaksi Non Tunai PT. Selecta}

Sumber: Diolah Peneliti (2018)

Berdasarkan gambar 3 grafik pendapatan transaksi non tunai PT. Selecta, pendapatan paling berasal dari penggunaan kartu debet dengan total pendapatan sebesar Rp 2.550.370.379 atau sekitar $81 \%$ dari seluruh total pendapatan non tunai, selanjutnya diikuti oleh pendapatan dari penggunaan kartu kredit sebesar Rp 383.484.701 atau sekitar 12,2\% dari total pendapatan dan pendapatan dari penggunaan lainnya sebesar Rp 208.311.294 atau sekitar $6,7 \%$ dari total pendapatan.

\section{Wahana Permainan}

Taman Rekreasi Selecta merupakan salah satu unit bisnis yang dimiliki oleh PT. Selecta. Taman Rekreasi Selecta yang dapat dijadikan sebagai salah satu referensi berlibur bagi keluarga, menjadikannya sebagai salah satu wahana wisata yang ramai dikunjungi orang, baik dari masyarakat Kota Batu sendiri maupun masyarakat pendatang, hal ini dikarenakan Taman Rekreasi Selecta menyediakan wahanawahana permainan yang cocok bagi keluarga. Taman Rekreasi Selecta memiliki 9 wahana permainan yang menarik, yaitu flying fox, sky bike, sepeda air, kora-kora, family coaster, cinema 4D, kuda keliling, kiddie ride dan water park.

Diantara 9 wahana permainan tersebut terdapat 7 wahana permainan yang telah menerapkan transaksi non tunai sebagai sistem transaksinya, yaitu sky bike, sepeda air, kora-kora, family coaster, cinema $4 \mathrm{D}$, kuda keliling dan kiddie ride, sedangkan untuk 2 wahana permainan lagi yaitu flying fox dan water park masih belum menerapkan transaksi non tunai. Penyebab belum bisa diterapkannya transaksi non tunai pada wahana permainan flying fox dikarenakan flying fox merupakan wahana permainan yang bersifat sewa, sehingga pengelola wahana permainan ini berkewajiban membayar biaya sewa kepada PT.Selecta atas kerjasama yang telah terjalin. Dengan begitu seluruh aktivitas dalam mengoperasikan wahana permainan menjadi kewenangan pihak ketiga. Sedangkan untuk wahana permainan water park dikarenakan adanya biaya jaminan untuk peminjaman alat pemandian, sehingga sistem ini menyulitkan apabila menggunakan non tunai. Kesulitan tersebut karena 1 mesin EDC hanya untuk 1 rekening, artinya jika pengunjung telah membayarkan biaya 
jaminan kepada wahana tersebut secara non tunai, maka untuk pengembalian biaya jaminan tersebut pengelola wahana perlu melakukan transaksi non tunai kepada mesin EDC milik pengunjung, namun dalam pelaksanaannya mesin EDC hanya dimiliki oleh unit usaha, sehingga hal ini menyebabkan kesulitan untuk menerapkan transaksi non tunai. Adapun denah wahana permainan Taman Rekreasi Selecta adalah sebagaimana Gambar 4 berikut

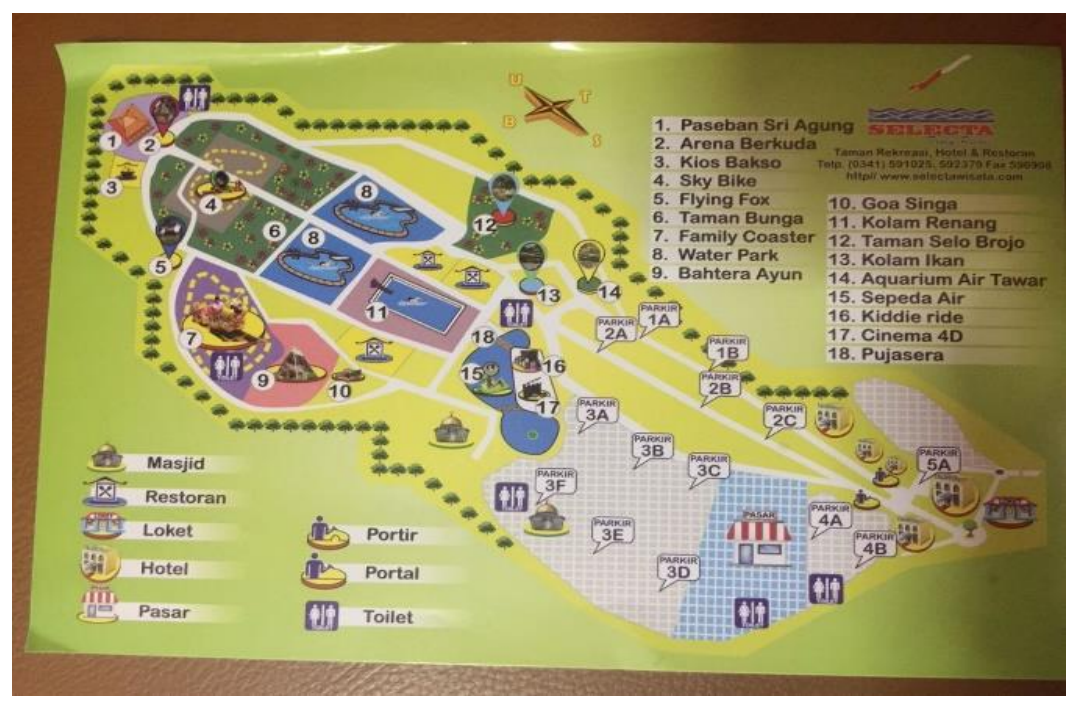

Gambar 4

Denah Taman Rekreasi Selecta

Sumber: PT.Selecta, 2018

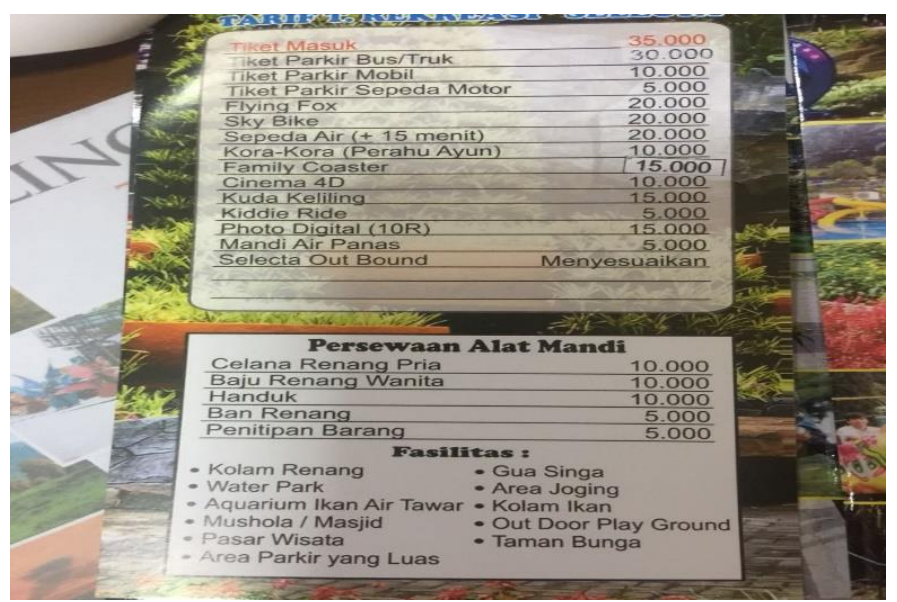

Gambar 5

Daftar Harga Wahana Permainan Taman Rekreasi Selecta

Sumber: Diolah Peneliti (2018)

Berdasarkan penjelasan yang disampaikan oleh Sujud selaku direktur PT.Selecta dan gambar 5 daftar harga wahana permainan Taman Rekreasi Selecta dapat diamati bahwa pada wahana water park memiliki fasilitas tambahan yang dapat disewa oleh pengunjung dan penyewaan tersebut dikenakan biaya jaminan sebesar 5 hingga 10 kali lipat dari total biaya penyewaan, sehingga hal ini menyulitkan penerapan transaksi non tunai, sedangakan flying fox ialah dikarenakan wahana permainan 
tersebut bersifat kerjasama dengan pihak ketiga sehingga seluruh wewenang operasional terhadap wahana permainan tersebut menjadi hak pihak ketiga dan manajemen PT.Selecta hanya menerima pendapatan sewa dari pihak ketiga tersebut.

\section{Implementasi Transaksi Non Tunai}

Transaksi non tunai merupakan bentuk transformasi dari sistem pembayaran. Transformasi tersebut dapat dilihat dari perubahan sistem bertransaksi yang awalnya hanya menggunakan instrumen tunai kemudian secara perlahan beralih dengan menggunakan instrumen non tunai. Transaksi non tunai pada dasarnya bertujuan untuk memenuhi kebutuhan masyarakat yang semakin kompleks dalam bertransaksi. Putri Sohfia selaku asisten manajer pengawasan sistem pembayaran Kantor Perwakilan Bank Indonesia Malang menyampaikan yang dimaksud dengan transaksi non tunai itu sebagai berikut:

"Jadi transaksi non tunai itu transaksi yang menggunakan APMK atau alat pembayaran menggunakan kartu, nah APMK itu ada kartu debet atau kartu ATM, ada kartu kredit, ada uang eletronik. Jadi transaksi non tunai ini transaksi yang digunakan dengan media APMK tersebut".

Tri Prasetyo Aribowo selaku pegawai pelaksana pengawasan sistem pembayaran Kantor Perwakilan Bank Indonesia Malang juga menyampaikan definisi dari transaksi non tunai tersebut, jadi transaksi non tunai itu adalah:

"Gerakan yang dicanangkan untuk mendorong masyarakat menggunakan sistem pembayaran dan instrumen pembayaran non tunai dalam melakukan transaksi pembayaran".

Transformasi yang terjadi pada sistem pembayaran memunculkan instrumen instrumen baru dalam bertransaksi, yaitu ketika awalnya masyarakat menggunakan uang (cash) dalam bertransaksi, namun kini sudah mulai menggunakan kartu (non cash) dalam bentuk kartu debet atau ATM, kredit atau uang elektronik yang disebut alat pembayaran menggunakan kartu (APMK). Putri Sohfia selaku asisten manajer pengawasan sistem pembayaran Kantor
Perwakilan Bank Indonesia Malang menjelaskan bahwa kemunculan transaksi non tunai bertujuan untuk mendukung strategi nasional keuangan inklusif pada tahun 2019, adapun penjelasannya ialah sebagai berikut:

"Jadi transaksi non tunai ini untuk mendukung program pemerintah. Jadikan di Indonesia sekarang ini jumlah bank people nya itu masih 34\%, jadi targetnya kita di 2019 ini sudah $75 \%$ dari penduduk Indonesa itu yang merupakan bank people. Jadi kalau misalnya kita ambil aja 200 juta jiwa, nah $75 \%$ nya kan berarti sekitar 150 juta jiwa, setidaknya dari 150 juta penduduk Indonesia itu sudah bisa punya akses terhadap lembaga keuangan. Jadi nggak harus dia punya rekening di bank, jadi untuk mencapai strategi itu salah satunya dengan penerapan uang elektronik untuk masuk ke jalan tol, untuk transportasi umum, atau yang salah satunya ini untuk masuk ke wahana wisata - wisata yang ada di Indonesia. Jadikan banyak tempat wisata di Indonesia, dengan adannya uang eletronik untuk masuk ke wahana wisata tersebut bisa meningkatkan jumlah bank people di Indonesia di tahun 2019 nanti. Jadi tujuannya untuk mendukung strategi nasional keuangan inklusif namanya di tahun 2019".

Selain untuk mendukung program pemerintah, transaksi non tunai juga ditujukan untuk efisiensi dan transparansi serta melindungi konsumen dalam bertransaksi, sebagaimana yang disampaikan oleh Tri Prasetyo Aribowo selaku pelaksana pengawasan sistem pembayaran Kantor Perwakilan Bank Indonesia Malang bahwa transaksi non tunai bertujuan untuk:

"Mendorong perilaku masyarakat untuk bertransaksi menggunakan sistem dan instrumen pembayaran secara non tunai agar lebih praktis, aman, efisien, transparan serta mendorong ekonomi yang lebih akurat".

Taman Rekreasi Selecta merupakan salah satu unit bisnis yang dimiliki oleh PT. Selecta. Taman Rekreasi Selecta telah menerapkan transaksi non tunai sejak akhir 2016. Manajemen PT. Selecta memutuskan menggunakan transaksi non tunai pada kegiatan operasional Taman Rekreasi Selecta disebabkan faktor keamanan dan untuk menjaga kepercayaan. Bagi manajemen PT. 
Selecta faktor keamanaan dalam bertransaksi menjadi faktor utama yang menjadi alasan diterapkannya transaksi non tunai. Dengan menerapkan transaksi non tunai, maka manajemen PT.Selecta dapat memaparkan laporan keuangan secara akuntabel dan transparan yang terintegrasi melalui sistem perbankan. Berdasarkan hasil penelitian, penerapan transaksi non tunai di Taman Rekreasi Selecta diinisiasi oleh Kantor Perwakilan Bank Indonesia Malang yang sedang gencar-gencarnya menggalakkan program Gerakan Nasional Non Tunai (GNNT). Berikut skema kerjasama penerapan transaksi non tunai yang terjadi di Taman Rekreasi Selecta:

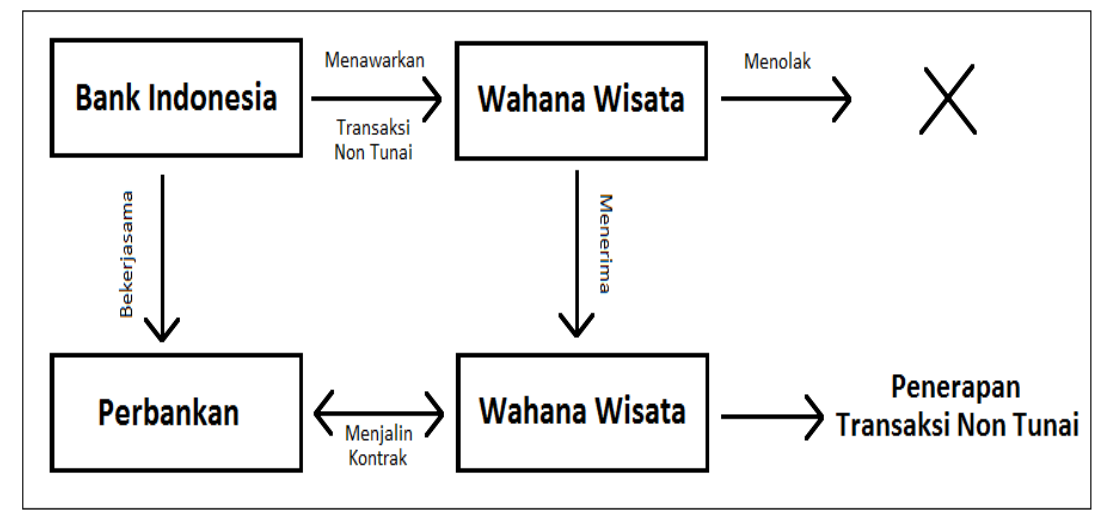

Gambar 6

Sumber: Diolah Peneliti, 2018

Skema Kerjasama Penerapan Transaksi Non Tunai

Berdasarkan skema pada Gambar 6 dapat diamati bahwa penerapan transaksi non tunai yang terjadi di Taman Rekreasi Selecta diawali dengan tawaran yang diberikan oleh Kantor Perwakilan Bank Indonesia Malang kepada PT.Selecta selaku wahana wisata yang bersedia menerapkan transaksi non tunai pada kegiatan operasional Taman Rekreasi Selecta. Kantor Perwakilan Bank Indonesia selaku regulator kebijakan transaksi non tunai bekerjasama dengan perbankan untuk mewujudkan penerapan transaksi non tunai di Taman Rekreasi Selecta. Perbankan selaku lembaga penyelenggara transaksi non tunai menyediakan fasilitas non tunai seperti mesin electronic data capture (EDC), kartu debet atau ATM, kredit dan uang elektronik. Taman Rekreasi Selecta selaku wahana wisata yang akan menggunakan transaksi non tunai menjalin kerjasama dengan perbankan agar diberikan fasilitas transaksi non tunai berupa mesin EDC. Selain menjalin kerja- sama dengan perbankan, manajemen PT. Selecta perlu menyediakan saluran internet agar dapat mengoperasikan mesin EDC yang langsung terintegrasi dengan sistem perbankan. Dengan proses tersebut, maka transaksi non tunai dapat diterapkan di Taman Rekreasi Selecta.

Perbankan yang menjalin kerjasama dengan PT. Selecta memiliki mesin EDC masing-masing untuk memfasilitasi transaksi non tunai yang akan berlangsung di Taman Rekreasi Selecta. Untuk memastikan proses transaksi non tunai berjalan dengan baik, pihak perbankan melakukan controlling secara berkala di Taman Rekreasi Selecta. Controlling dilakukan setiap bulan dengan mensurvey secara langsung ke Taman Rekreasi Selecta atau melalui telepon untuk memastikan tidak adanya kendala ataupun kerusakan terhadap mesin EDC atau proses transaksi yang dilakukan. Berikut peneliti sajikan proses transaksi non tunai yang diterapkan di Taman Rekreasi Selecta: 


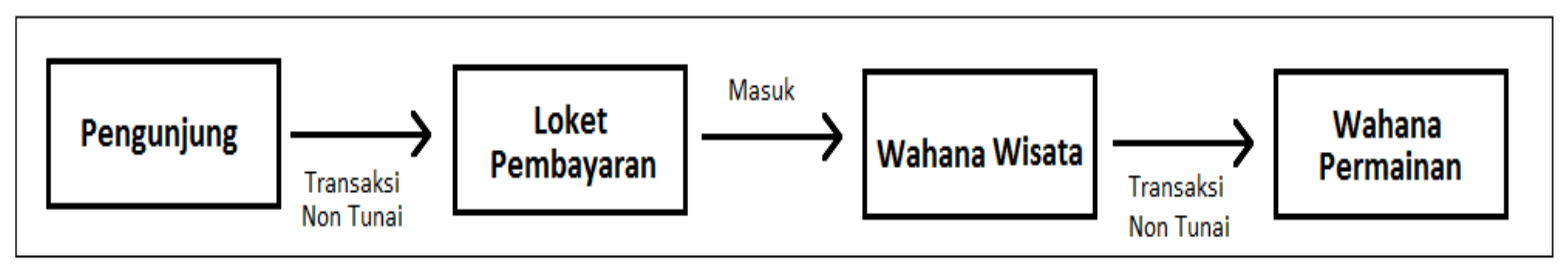

Gambar 7

Sumber: Diolah Peneliti, 2018

Skema Transaksi Non Tunai Taman Rekreasi Selecta

Penerapan transaksi non tunai di Taman Rekreasi Selecta dapat diamati berdasarkan skema diatas. Pengunjung melakukan transaksi non tunai di beberapa lokasi, yaitu di loket pembayaran dan wahana permainan. Di loket pembayaran Taman Rekreasi Selecta yang menerapkan sistem drive thru, pengunjung melakukan transaksi non tunai agar dapat masuk ke dalam wahana wisata. Kemudian di wahana permainan, pengunjung juga dapat melakukan transaksi non tunai di setiap wahana yang ingin dimainkan.

\section{Manfaat dan Tantangan Transaksi Non Tunai}

Implementasi Transaksi non tunai yang merupakan transformasi sistem pembayaran merupakan suatu solusi bagi masyarakat dalam menyelesaikan permasalahan-permasalahan yang muncul dari penerapan transaksi tunai, seperti perampokan, pencucian uang, korupsi dan lain sebagainya. Kemunculan transaksi non tunai ini dapat memberikan dampak positif dalam bertransaksi. Hasil analisis yang dilakukan oleh peneliti berdasarkan hasil wawancara, observasi dan kajian pustaka, menemukan bahwa transaksi non tunai itu:

\section{a. Aman}

Faktor keamanan menjadi perhatian utama dalam bertransaksi. Penggunaan transaksi non tunai memberikan keamanan kepada setiap penggunanya berupa kemananan aset dan pengunaan sistem pin atau password. Manajemen PT. Selecta mengakui dengan diterapkannya sistem transaksi non tunai dapat lebih membantu dalam menjaga asetnya, apalagi Taman
Rekreasi Selecta yang tergolong jauh dari keraiaman dengan pendapatan dalam 1 hari weekend bisa mencapai ratusan juta, sehingga hal ini menyebabkan Taman Rekreasi Selecta sangat rentan timbulnya tindak kejahatan kriminial. Namun, dengan diterapkannya transaksi non tunai tersebut seluruh pendapatan yang diterima oleh PT. Selecta dapat tersimpan secara aman oleh sistem dan pengeluaran atas biaya-biaya dapat dilakukan tanpa khawatir dengan tindakan kejahatan kriminal.

\section{b. Efisien}

Transaksi non tunai memberikan kemudahan kepada setiap penggunanya karena bisa dilakukan kapan saja dan dimana saja, sehingga hal ini lebih mengefisiensi waktu pengguna transaksi non tunai. Selain kemudahan, transaksi non tunai juga sangat cepat. Hal ini dikarenakan pengguna tidak perlu repot-repot datang ke merchant-merchant untuk proses transaksi pembayaran, tapi cukup melakukan transfer secara online. Allah Swt. berfirman di dalam Al-Qur'an surah Al Isra' atau 17: 26, yaitu:

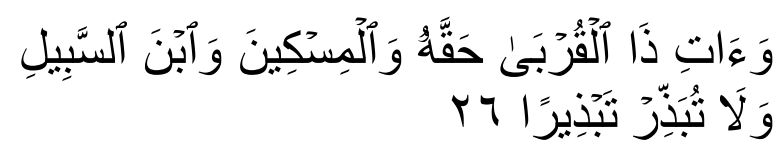

"Dan berikanlah kepada keluarga-keluarga yang dekat akan haknya, kepada orang miskin dan orang yang dalam perjalanan dan janganlah kamu menghambur-hamburkan (hartamu) secara boros" (Qs. Al Isra' atau $17: 26)$.

Allah Swt. menyatakan agar kita tidak berlaku boros. Salah satu kemunculan transaksi non tunai ialah dalam rangka menekan biaya, begitu banyak biaya yang 
perlu dikeluarkan dalam proses pembuatan uang, mulai dari biaya desain, pencetakan, pendistribusian hingga biaya pemusnahan uang yang sudah tidak layak edar. Dengan menerapkan transaksi bersifat non tunai berarti pengguna telah mengurangi pemborosan tersebut.

Manfaat efisiensi juga dirasakan oleh Taman Rekreasi Selecta, yaitu pengunjung yang ingin booking dapat melakukan pembayaran secara transfer, sehingga menghemat waktu dan biaya perjalanan. Selain itu, pendapatan Taman Rekreasi Selecta yang dapat mencapai ratusan juta membutuhkan ruang penyimpanan yang besar, agar dapat menampung jumlah uang yang banyak. Akan tetapi dengan transaksi non tunai, jumlah uang yang besar tersebut dapat langsung tersetorkan ke perbankan dan dapat di cek melalui rekening PT. Selecta, sehingga lebih menghemat ruang penyimpanan Taman Rekreasi Selecta.

\section{c. Akuntabel dan Transparan}

Akuntabel dan transparansi menjadi salah satu manfaat yang diterima dengan menerapkan sistem transaksi non tunai. Hal ini dikarenakan seluruh pemasukan dan pengeluaran yang dilakukan secara non tunai akan tercatat secara jelas dan rinci oleh sistem, sehingga selaku pengguna dapat melihat berapa pemasukan dan pengeluaran yang dilakukan serta berasal darimana pendapatan tersebut atau kemana pengeluaran tersebut disalurkan melalui rekening koran. Manfaat akuntabel dan transparan ini juga tercermin di dalam Al Qur'an surah $\mathrm{Al}$ Baqarah/ $2: 282$, yaitu:

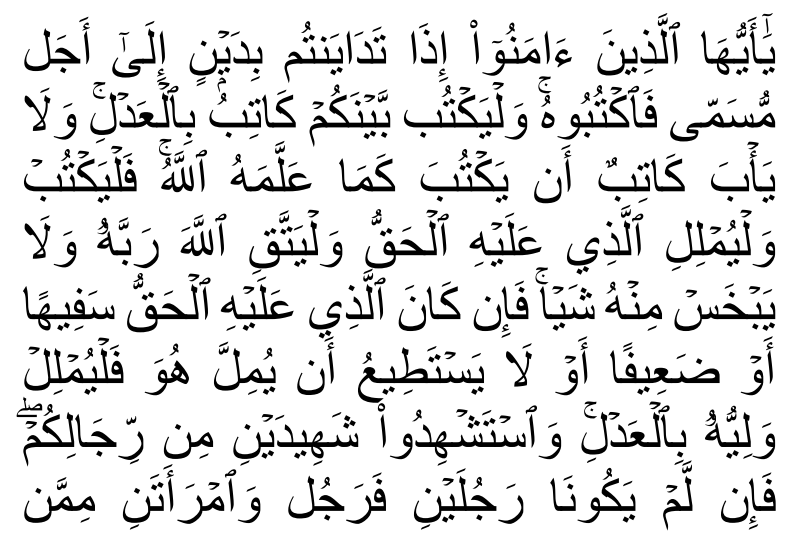

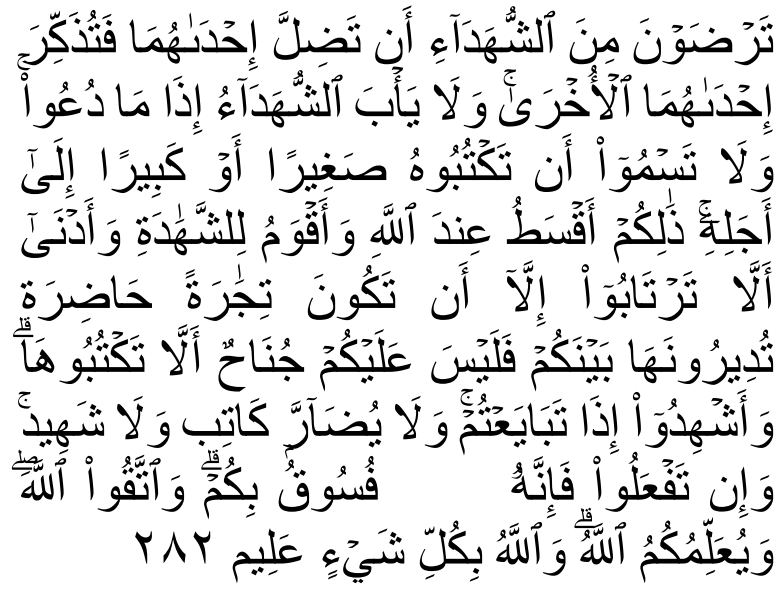

"Hai orang-orang yang beriman, apabila kamu bermu'amalah tidak secara tunai untuk waktu yang ditentukan, hendaklah kamu menuliskannya. Dan hendaklah seorang penulis di antara kamu menuliskannya dengan benar. Dan janganlah penulis enggan menuliskannya sebagaimana Allah telah mengajarkannya, maka hendaklah ia menulis, dan hendaklah orang yang berhutang itu mengimlakan (apa yang akan ditulis itu), dan hendaklah ia bertakwa kepada Allah Tuhannya, dan janganlah ia mengurangi sedikitpun daripada hutangnya. Jika yang berhutang itu orang yang lemah akalnya atau lemah (keadaannya) atau dia sendiri tidak mampu mengimlakan, maka hendaklah walinya mengimlakan dengan jujur. Dan persaksikanlah dengan dua orang saksi dari orang-orang lelaki di antaramu). Jika tak ada dua orang lelaki, maka (boleh) seorang lelaki dan dua orang perempuan dari saksi-saksi yang kamu ridhai, supaya jika seorang lupa maka seorang lagi mengingatkannya. Janganlah saksi-saksi itu enggan (memberi keterangan) apabila mereka dipanggil; dan janganlah kamu jemu menulis hutang itu, baik kecil maupun besar sampai batas waktu membayarnya. Yang demikian itu, lebih adil di sisi Allah dan lebih dapat menguatkan persaksian dan lebih dekat kepada tidak (menimbulkan) keraguanmu, (Tulislah mu'amalahmu itu), kecuali jika mu'amalah itu perdagangan tunai yang kamu jalankan di antara kamu, maka tak ada dosa bagi kamu, (jika) kamu tidak menulisnya. Dan persaksikanlah apabila kamu berjual-beli; dan janganlah penulis dan saksi saling sulit-menyulitkan. Jika kamu lakukan (yang demikian), maka sesungguhnya hal itu adalah suatu kefasikan pada dirimu. Dan bertakwalah kepada Allah, Allah mengajarmu 
dan Allah Maha Mengetahui segala sesuatu" (Q.S Al Baqarah atau 2: 282).

Secara jelas dinyatakan di dalam $\mathrm{Al}$ Qur'an bahwasanya tindakan pencatatan tersebut sangat perlu dilakukan untuk saling menjaga kepercayaan, berlaku adil terhadap sesama dan mengindari tindakan curang serta dengan proses pencatatan yang jelas maka transparansi juga akan tercipta. Manajemen PT. Selecta yang turut berkontribusi demi terwujudnya less cash society sangat ingin menjaga kepercayaan para pemegang sahamnya dengan menunjukkan etos kerja yang baik melalui nilai kejujuran dan transparansi, hal ini dibuktikan dengan adanya pencatatan yang baik melalui sistem perbankan, yaitu dengan penerapan transaksi non tunai.

\section{d. Praktis}

Berbeda halnya dengan transaksi tunai, transaksi non tunai sangat praktis karena pengguna tidak perlu membawa uang tunai kemana-mana, tapi cukup menyimpan uangnya dalam bentuk elektronik. Penyimpanan uang secara non tunai dapat dilakukan melalui 2 cara, yaitu secara chip based atau server based. Chip based ialah penyimpanan uang melalui media kartu seperti kartu debet atau ATM, kredit atau uang elektronik, sedangkan server based ialah penyimpanan uang yang berbasis server atau dengan menggunakan aplikasi tertentu seperti go pay, T-Cash dan lain sebagainya.

Manfaat kepraktisan yang dirasakan oleh Taman Rekreasi Selecta yaitu tidak perlu menyimpan uang tunai dalam jumlah yang besar. Pendapatan yang diterima menggunakan transaksi non tunai dapat secara langsung terintegrasi dengan sistem perbankan sehingga nominal pendapatan dapat diketahui melalui rekening PT.Selecta yang ada di perbankan.

\section{e. Mencegah Kecurangan}

Manfaat lain yang didapatkan dengan menerapkan transaksi non tunai ialah dapat mencegah tindakan kecurangan. Kecurangan-kecurangan yang umumnya telah dilakukan seperti peredaran uang palsu, tindak korupsi, pembelian barang-barang terlarang, dan lain sebagainya dapat ditekan dan segera ditanggulangi dengan menerapkan transaksi non tunai yang seluruh pencatatan arus keuangan ter-record dengan baik, sehingga tindakan-tindakan kecurangan yang dilakukan dapat diidentifikasi dengan segera bersumber darimana dan disalurkan kemana. Allah Swt. berfirman di dalam surah Al Muthaffifin atau 83 : 1-3, yaitu:

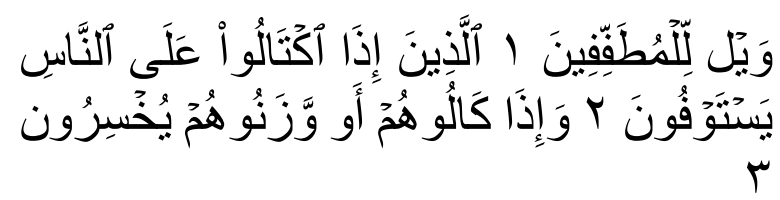

"Kecelakaan besarlah bagi orang-orang yang curang, (yaitu) orang-orang yang apabila menerima takaran dari orang lain mereka minta dipenuhi, dan apabila mereka menakar atau menimbang untuk orang lain, mereka mengurangi" (Q.S Al Muthaffifin atau $83: 1-3$ ).

Melalui Al Qur'an Allah Swt. Mengancam orang-orang yang berbuat kecurangan dengan celaka yang besar, sehingga dibutuhkannya nilai kejujuran agar tidak adanya tindakan curang dalam bekerja. Dalam penerapan transaksi tunai di Taman Rekreasi Selecta Sujud selaku direktur PT.Selecta mengakui jika ada kehilangan 1 atau 2 transaksi itu sudah hal biasa. Namun, dengan penerapan transaksi non tunai secara perlahan tindakan kecurangan tersebut mulai memudar.

Selain manfaat-manfaat diatas Sujud selaku direktur PT. Selecta juga menjelaskan manfaat-manfaat lain yang diterima oleh PT. Selecta maupun yang diberikan PT. Selecta kepada pengunjung. Taman Rekreasi Selecta memberikan kompensasi kepada pengunjung yang menggunakan kartu kredit dengan cara pembebasan bunga kredit, sehingga yang menanggulangi biaya tersebut ialah PT. Selecta.

Dari sekian banyak manfaat yang didapatkan, transaksi non tunai tidak terlepas dari tantangan-tantangan yang muncul dalam proses pengoptimalannya, adapun tantangan-tantangan yang muncul adalah sebagai berikut: 
a. Keterbatasan Sinyal

Sinyal menjadi kunci utama dalam menerapkan transaksi non tunai. Kondisi georgrafis Taman Rekreasi Selecta yang jauh dari keramian dan minim sinyal membuat proses transaksi non tunai sedikit terhambat, hal ini juga dikarenakan tidak adanya tower provider disekitar Taman Rekreasi Selecta, sehingga ketika proses pembayaran dengan sinyal yang lambat tidak jarang terjadi error system yang akhirnya berdampak pada penumpukan kendaraan yang menyebabkan kemacetan pada area loket karcis Taman Rekreasi Selecta, karena Taman Rekreasi Selecta menerapkan sistem drive thru pada loket karcis.

b. Permasalahan Sumber Daya Manusia

Memiliki sumber daya manusia yang kompeten merupakan faktor penting dalam mengoperasikan sistem transaksi non tunai yang berbasis teknologi. Pelatihan dan pengembangan perlu dilakukan agar sumber daya yang dimiliki cakap secara skill dan dapat melayani pengunjung dengan lebih baik lagi. Selain itu, proses dua kali debet juga merupakan salah satu kecurangan yang umum terjadi dalam penerapan transaksi non tunai, sehingga perusahaan perlu melakukan pemberdayaan yang baik terhadap pegawainya agar kecurangan-kecurangan ini tidak terjadi dan merugikan konsumen atau pengunjung.

c. Sistem yang Belum Terintegrasi

Sistem yang belum terintegrasi dengan baik juga merupakan tentangan tersendiri yang dialami oleh unit accounting PT. Selecta. Berdasarkan keterangan yang diberikan oleh Tri Suhartin selaku accounting PT. Selecta bahwa sistem yang dimiliki oleh Taman Rekreasi Selecta masih belum terintegrasi dengan baik sehingga dalam proses perekapan transaksi unit accounting perlu menghitung satu persatu transaksi yang ada dan kemudian menjumlahkannya. Selain itu, manajemen PT.Selecta juga menerapkan strategi dual system transaction, yaitu penerapan transaksi tunai dan non tunai secara bersamaan. Penerapan dual system transaction memberikan tantangan tersendiri bagi unit accounting untuk mengidentifikasi transaksi tunai dan non tunai yang masuk sebagai pendapatan Taman Rekresi Selecta. d. Kurangnya Loyalitas Masyarakat

Rendahnya penggunaan non tunai di masyakat menjadi permasalahan utama sampai saat ini. Kurangnya loyalitas terhadap penggunaan transaksi non tunai dan kesetiaan masyarakat terhadap transaksi tunai membuat transaksi non tunai cukup sulit untuk diterapkan. Berbagai penyebab muncul dikalangan masyarakat, mulai dari keterbatasan akses terhadap non tunai, kurangnya sarana dan prasarana, hingga pengeluaran yang kecil dan beranggapan lebih cepat menggunakan tunai. Ini yang menyebabkan penerapan transaksi non tunai di Taman Rekreasi Selecta juga masih tergolong rendah.

\section{SIMPULAN DAN SARAN Simpulan}

Penerapan transaksi non tunai pada Taman Rekreasi Selecta diinisiasi oleh Kantor Perwakilan Bank Indonesia Malang dalam rangka menggalakkan program Gerakan Nasional Non Tunai (GNNT). Dalam pelaksanaannya Kantor Perwakilan Bank Indonesia Malang bekerjasama dengan perbankan selaku fasilitator transaksi non tunai untuk menerapkan transaksi non tunai pada Taman Rekreasi Selecta. Taman Rekreasi Selecta selanjutnya dapat menerapkan transaksi non tunai pada loket karcis dan wahana permainan, sehingga pengunjung dapat melakukan transaksi non tunai sesuai dengan wahana yang ingin dimainkan.

Dalam prosesnya Taman Rekreasi Selecta merasakan manfaat dan tantangan dalam mengimplementasikan transaksi non tunai pada kegiatan operasionalnya. Adapun manfaat yang dirasakan oleh Taman Rekreasi Selecta adalah meningkatnya keamanan terutama dari tindak kejahatan, efisiensi waktu dan biaya, akuntabel dan transparan dalam segala jenis transaksi yang terjadi, praktis dibawa kemana saja dan tidak menyita ruang, serta tercegahnya dari tindakan kecurangan. Sedangkan tantangan yang dirasakan dalam menerapkan transaksi non tunai ialah keterbatasan sinyal yang 
disebabkan kondisi geografis, permasalahan pada sumber daya manusia, sistem yang belum terintegrasi dengan baik dan kurangnya loyalitas masyarakat untuk menggunakan non tunai.

Dengan diterapkan transaksi non tunai pada kegiatan operasionalnya, Taman Rekreasi Selecta turut mendukung dan berkontribusi nyata dalam mewujudkan less cash society. Walaupun pertumbuhan transaksi non tunai masih berkisar 5\%, akan tetapi jumlah tersebut telah berhasil disumbangkan Taman Rekreasi Selecta untuk menambah jumlah bank people di Indonesia, karena dengan bertambahnya jumlah bank people, maka akan meningkatkan angka keberhasilan less cash society di Indonesia

\section{Saran}

Penerapan transaksi non tunai pada Taman Rekreasi Selecta memberikan dampak positif bagi internal perusahaan. Untuk memberikan layanan yang prima kepada pengunjung, alangkah baiknya jika manajemen PT. Selecta dapat menjalin kerjasama dengan pihak provider dalam rangka pembuatan tower sinyal, sehingga permasalahan yang muncul diakibatkan oleh keterbatasan sinyal dapat segera teratasi dan diadakannya upgrading untuk peningkatan kualitas SDM, karena transaksi non tunai merupakan bentuk kemajuan teknologi dan teknologi akan terus berkembang. Penelitian ini dapat dijadikan sebagai referensi oleh stakeholder wahana wisata lainnya, karena dengan menerapkan transaksi non tunai pada kegiatan operasional wahana wisata bisa memperoleh banyak manfaat, diantaranya aman, efisien, praktis, akuntable dan transparan. Selain itu, juga akan menumbuhkan nilai kejujuran dalam bekerja sehingga dapat meningkatkan kredibilitas perusahaan, terutama bagi pemegang saham.

\section{DAFTAR PUSTAKA}

Abdussakur. 2012. Implementasi Kebijakan Anggaran Pendapatan dan Belanja Desa (APBDes) di Wilayah Kecamatan Batu Benawa Kabupaten Hulu Sungai Tengah Provinsi Kalimantan Selatan.
Jurnal Ilmu Politik dan Pemerintahan Lokal, 1(2): 107-136.

Abidin, M. S. 2015. Dampak Kebijakan EMoney Di Indonesia Sebagai Alat Sistem Pembayaran Baru. Jurnal Akuntansi UNESA 3(2).

Akib, H. 2010. Implementasi Kebijakan: Apa, Mengapa, dan Bagaimana. Jurnal Administrasi Publik 1(1): 1-11.

Ariyani, Y. 2016. Analisis Perilaku Masyarakat Bertransaksi Non Tunai (Studi Kasus Pengunjung Pusat Perbelanjaan di Kawasan Malioboro). http://repository. umy.ac.id/bitstream/handle/123456789/829 6/naskah\%20publikasi.pdf? sequence $=1$

Bank Indonesia. 2006. Pengantar Sistem Pembayaran. Bank Indonesia. Jakarta.

Bank Indonesia. 2012. Menguak Potensi Sistem Pembayaran Bagi Perekonomian. Bank Indonesia. Jakarta.

Borzekowski, R., E. K. Kiser, dan S. Ahmad. 2006. Consumer's use of debit cards: patterns, preferences, and price response. Journal of Money, Credit and Banking 40(1): 149-172.

Bounie, D. dan A. Francois. 2009. Cash, Check or Debit Card? The effects of transaction characteristics on the use of payment instrument. Seminar at the workshop at the SES Telecom Paris, Economics and Social Sciences: 1-17.

Bungin, B. 2015. Penelitian Kualitatif. Prenada Media Group. Jakarta.

Choe, H., S. J. Yoon, dan D. P. Johnson. 1991. Gender differences in the choice of payment method for purchasing durable goods. Gender and Consumer Behaviour Conference Proceedings University of Utah, Salt Lake City: 19-23.

Creswell, J. W. 2015. Penelitian Kualitatif dan Desain Riset. Pustaka Pelajar. Yogyakarta.

Dehghan, F. dan A. Haghighi. 2015. E-Money Regulation For Consumer Protection. International Journal of Law and Management 57(6): 610-620.

Feinberg, R. A. 1986. Credit cards as spending facilitating stimuli: a conditioning interpretation. Journal of Consumer Research 12: 384-356. 
Foscht, Maloles, Swoboda, dan Chia. 2010. Debit and Credit Card Usage and Satisfaction. International Journal of Bank Marketing 28(2): 150-165.

Goldstrucker, J. dan E. C. Hirschman. 1977. Bank Credit Card Users: a New Market Segment for Regional Retailers. MSU Business Topics 25(3): 5-11.

Gourville, T. dan D. Soman. 1998. Payment Depreciation: the Behavioural Effects of Temporally Separating Payments from Consumption. Journal of Consumer Research 25: 160-174.

Hadiwijoyo, S. S. 2012. Perencanaan Pariwisata Pedesaan Berbasis Masyarakat: Sebuah Pendekatan Konsep. Graha Ilmu. Yogyakarta.

Helmi, R. dan Z. Mubarak. 2014. Analisis Faktor-Faktor yang Mempengaruhi Masyarakat Kalimantan Selatan Terhadap Penggunaan Pembayaran Non Tunai. At-Taradhi: Jurnal Studi Ekonomi, 5(1).

Hirschman, E. C. 1979. Differences in Consumer Purchase Behaviours by Credit Card Payment System. Journal of Consumer Research 6: 58-66.

Kartika, V. T. dan A. B. Nugroho. 2015. Analysis on Electronic Money Transactions on Velocity of Money in Asean5 Countries. Journal of Business and Management 4(9).

Klee, E. 2004. Paper or Plastic: The Effect of Time on Check and Debit Card Use at Grocery Stores. http://ssm.com/abstract= 687159.

Kumari, N. dan J. Khanna. 2017. Cashless Payment: A Behaviourial Change to Economic Growth. International Journal of Scientific Research and Education 5(7): 6701-6710.

Lee, J. dan K. Kwon. 2002. Consumers' Use of Credit Cards: Store Credit Card Usage as an Alternative Payment and Financing Medium. The Journal of Consumer Affairs 36: 239-262.

Libow, V. 1955. Sustainable Consumption. The Journal of Retailing 7: 29-31.

Mann, R. J. 2002. Credit Cards and Debit Cards in the United States and Japan.
Monetary and Economic Studies 20(1): 123159.

Martell, T. dan R. Fitts. 1981. A Quadratic Discriminant Analysis of Bank Credit Card User Characteristics. Journal of Economics and Business 33(Winter): 153159.

Mathews, H. L. dan J. W. Slocum. 1969. Social Class and Commercial Bank Card Usage. Journal of Marketing 33: 71-78.

Mathews, H. L. dan J. W. Slocum. 1970. Rejoinder Tosocial Class or Income? Journal of Marketing 36: 69-70.

McCall dan Belmont. 1996. Credit card insignia and restaurant tipping: Evidence for an associative link. McCall, Michael; Belmont, Heather J. Journal of Applied Psychology 81(5): 609-613.

McCall, M., J. Trombetta, dan A. Gipe. 2004. Credit cues and impression management: a preliminary attempt to explain the credit card effect. Psychological Reports 9: 331-337.

McDonald, S., C. J. Oates, W. Young, dan K. Hwang. 2006. Toward sustainable consumption: researching voluntary simplifiers. Psychology and Marketing 23(6): $515-534$.

Miles, M. B. dan A. M. Huberman. 2007. Qualitative Data Analysis. UI Press. Jakarta.

Ozturk, A. B. 2016. Customer Acceptance of Cashless Payment Systems In The Hospitality Industry. International Journal of Contemporary Hospitality Management 28(4): 801-817.

Parikeit, D. dan W. Trisnadi. 1997. Kebijakan Kepariwisataan Indonesia dalam Pembangunan Jangka Panjang. Kelola, 6(16).

Plummer, J. T. 1971. Life style patterns \&commercial bank credit card usage. Journal of Marketing 35: 35-41.

Pramono, B., T. Yanuarti, P. D. Purusitawati, dan Y. T. Emmy. 2006. Dampak Pembayaran Non Tunai terhadap Perekonomian dan Kebijakan Moneter. Working Paper Bank Indonesia. Jakarta.

Pramudita, A., H. Lestari, dan S. Sulandari. 2013. Implementasi Pembangunan Kepariwisataan di Taman Margasatwa 
Mangkang Kota Semarang. Journal of Public Policy and Management Review 2(1). Prelec, D. dan G. Loewenstein. 1998. The red \& the black: mental accounting of savings and debt. Marketing Science 17: 428.

Prelec, D. dan D. Simester. 2001. Always leave home without it: a further investigation of the credit-card effect on willingness to pay. Marketing Letters 12(2): 5-12.

Prendergast, G. P. 1993. Self-service technologies in retail banking: current andexpected adoption patterns. International Journal of Bank Marketing 11(7): 29-35.

Raghubir, P. dan J. Srivastava. 2008. Monopoly money: the effect of payment coupling andform on spending behaviour. Journal of Experimental Psychology: Applied 14(3): 213-225.

Ramadani, L. 2016. Pengaruh Penggunaan Kartu Debit dan Uang Elektronik (EMoney) Terhadap Pengeluaran Konsumsi Mahasiswa. Jurnal Ekonomi dan Studi Pembangunan 8(1).

Segara, T. 2014. Bank Indonesia Mencanangkan Gerakan Non Tunai. https:// www.bi.go.id/id/ruang-media/siaran-pers/

Pages/sp_165814.aspx. Diakses tanggal 14 Desember 2017.

Singh. 2004. Impersonalisation of electronic money: implications for bank marketing. The International Journal of Bank Marketing 22(7): 504-521.

Soman, D. 2001. Effects of payment mechanism on spending behaviour: The role of rehearsal immediacy of payments. Journal of Consumer Research 27: 460-471.
Soman, D. 2003. The Effect of Payment Transparency on Consumption: Quasi Experiments from the Field. Marketing Letters 14(3): 173-183.

Subari, S. M. T. dan Ascarya. 2003. Kebijakan Sistem Pembayaran di Indonesia. Pusat Pendidikan dan Studi Kebanksentralan (PPSK) Bank Indonesia. Jakarta.

Sugiyono. 2013. Metode Penelitian Bisnis. Alfabeta. Bandung.

Thaler, R. H. 1985. Mental accounting \& consumer choice. Marketing Science 4: 199-214.

Thaler, R. H. 1999. Mental accounting matters. Journal of Behavioural Decision Making 12: 183-206.

Thomas, M., K. K. Desai, dan S. Seenivasan. 2011. How Credit Card Payments Increase Unhealthy Food Purchases: Visceral Regulation of Vices, Journal of Consumer Research 38(June).

Undang-Undang Republik Indonesia Nomor 10 Tahun 2009 tentang Kepariwisataan.

Wulandari, D., T. Soseco, dan B. S. Narmaditya. 2016. Analysis of the Use of Electronic Money in Efforts to Support the Less Cash Society. Macrothink Institute 3(1).

Yuningsih, N. 2005. Peningkatan Pendapatan Asli Daerah (PAD) melalui Pengembangan Potensi Obyek Wisata Pantai Pangandaran di Kabupaten Ciamis Jawa Barat. Skripsi. Fakultas Ilmu Sosial Universitas Negeri Semarang. Semarang.

Zavestoski, S. 2002. The social-psychological bases of anticonsumption attitudes. Psychology \& Marketing, 19: 149-165 